\title{
Ascendency as ecological indicator for environmental quality assessment at the ecosystem level: a case study
}

\author{
J. Patrício ${ }^{1, *}$, R. Ulanowicz ${ }^{2}$, M. A. Pardal ${ }^{1} \&$ J. C. Marques ${ }^{1}$ \\ ${ }^{1}$ IMAR-Institute of Marine Research, Department of Zoology, Faculty of Sciences and Technology, \\ University of Coimbra, 3004-517, Coimbra, Portugal \\ ${ }^{2}$ Chesapeake Biological Laboratory, Center for Environmental and Estuarine Studies, \\ University of Maryland, Solomons, Maryland, 20688-0038, USA \\ (*Author for correspondence: E-mail: jpatricio@ci.uc.pt)
}

Key words: network analysis, ascendency, eutrophication, estuary

\begin{abstract}
Previous studies have shown that when an ecosystem consists of many interacting components it becomes impossible to understand how it functions by focussing only on individual relationships. Alternatively, one can attempt to quantify system behaviour as a whole by developing ecological indicators that combine numerous environmental factors into a single value. One such holistic measure, called the system 'ascendency', arises from the analysis of networks of trophic exchanges. It deals with the joint quantification of overall system activity with the organisation of the component processes and can be used specifically to identify the occurrence of eutrophication. System ascendency analyses were applied to data over a gradient of eutrophication in a well documented small temperate intertidal estuary. Three areas were compared along the gradient, respectively, non eutrophic, intermediate eutrophic, and strongly eutrophic. Values of other measures related to the ascendency, such as the total system throughput, development capacity, and average mutual information, as well as the ascendency itself, were clearly higher in the non-eutrophic area. When the whole-system properties of the three areas were compared, however, the values associated with the intermediate eutrophic area turned out to be the lowest, which possibly could be attributed to the unstable nature of this area. The current study provided an example of how the measures arising out of network analysis might lead to an improved understanding of the system functioning and of the eutrophication process itself.
\end{abstract}

\section{Introduction}

Ecology can be defined as the scientific study of the relationships between organisms and their environment; and, in general, can be approached from two directions: (1) as reductionism, wherein each relationship is considered by itself and the results are assembled afterwards; and (2) as holism, whereby the system is considered in its entirety and a search is undertaken to reveal properties at the system level (Jørgensen, 1997).

Previous studies have shown that an ecosystem consists of so many interacting components that it becomes impossible ever to understand how it functions by examining the component relationships in isolation. Often, when individual components of ecosystems are studied via reductionism, the reconstructed ensemble will behave differently than the sum of the parts.

To obviate such problems, one might attempt to describe phenomenologically at least part of the reality of ecosystems structure by developing ecological indicators that combine numerous environmental factors into a single value, in the hope 
that such an index will be useful in connecting empirical research, modelling and management (Patten et al., 2002 a, b). It is envisioned that such indicators will provide synoptic information about the state of the ecosystems they represent. Most often, they address an ecosystem's structure or functioning and encompass specific aspects or components, such as nutrient concentrations, the pattern of water flows, the diversity of vertebrates or macroinvertebrates, plant diversity, etc. Sometimes, however, they are intended to address the ecological integrity of the system as a whole.

One such holistic measure derives from the analysis of networks of trophic exchanges and is called the system 'ascendency'. Ulanowicz (1980) defines ascendency as an index that quantifies both the level of system activity and the degree of the organization with which it processes material in autocatalytic fashion. The level of activity is measured by the sum of the magnitudes of all the trophic exchanges occurring in the system, or what is called the 'total system throughput' (TST.) The organisation of the flow structure is captured by the average mutual information (AMI) inherent in how the flows are put together (Rutledge et al., 1976.) Ascendency varies jointly as (is the product of) both of these network characteristics (see below.)

Although ascendency is a rather abstract concept, it possesses manifold attributes that are useful in a number of practical circumstances - for example, quantifying the status of an ecosystem (Baird \& Ulanowicz, 1989; Halfon et al., 1996; Wolff et al., 1996; Heymans \& Baird, 2000; Ray \& Ulanowicz, 2000), measuring the effects of perturbations on it (Baird \& Heymans, 1996; Almunia et al., 1999), assessing its health and integrity (Constanza, 1992), and comparing ecosystems one with another (Baird \& Ulanowicz, 1989; Heymans \& Baird, 1995; Baird et al., 1991; Monaco \& Ulanowicz, 1997). Recently, the organizational factor in the ascendency has been shown to be equal to the logarithm of the number of effective trophic levels inherent in the system (Zorach \& Ulanowicz, 2003.)

An enormous number of studies have shown unambiguously that most European and North American estuaries are affected to some degree by organic pollution and nutrient discharges, often to an extent that gives rise to eutrophication and its linked effects upon resident biota (Diaz \& Rosenberg, 1995; Norkko \& Bonsdorff, 1996; Flindt et al., 1997; Marques et al., 1997; Weaver et al., 1997; Raffaelli et al., 1998; Cloern, 2001). Using ascendency, it becomes possible to determine quantitatively whether a disturbed system has grown or shrunk, developed or regressed. Furthermore, the process of eutrophication can be defined in terms of its network attributes as any increase in system ascendency (due to a nutrient enrichment) causes a rise in total system throughput which more than compensates for a concomitant fall in the mutual information (Ulanowicz, 1986).

The aim of this study was to test whether this network definition of eutrophication properly tracks changes in community structure along a gradient of eutrophication existing in the south arm of the Mondego estuary (Portugal), a small and well described temperate intertidal estuary (eg. Marques et al., 1997, 2003; Pardal et al., 2000; 2004; Cardoso et al., 2002).

\section{Material and methods}

\section{Study area}

The Mondego estuary, situated along the western coast of Portugal, is bifurcated into a northern and southern arm, each exhibiting very different hydrological characteristics (Fig. 1). The northern arm is deeper, while the southern arm is silted up, especially in upstream areas, which causes most of the freshwater discharge to flow through the northern arm. This siltation diverts most of the freshwater discharge into the northern arm. As a consequence, the water circulation in the southern arm is dependent mainly on tidal flushing and on a relatively small input of freshwater from the Pranto River, the flow of which is controlled artificially by a sluice.

Macroalgal blooms of Enteromorpha intestinalis (Linnaeus) Link and Enteromorpha compressa (Linnaeus) Greville have been observed with regularity in the Mondego over the last twenty years (Flindt et al., 1997; Marques et al., 1997, 2003; Lillebø et al., 1999; Pardal et al., 2000, 2004; Martins et al., 2001; Cardoso et al., 2002; Dolbeth et al., 2003). Nevertheless, such macroalgal blooms may not occur in exceptionally rainy years. This is most probably due to the resulting long periods 


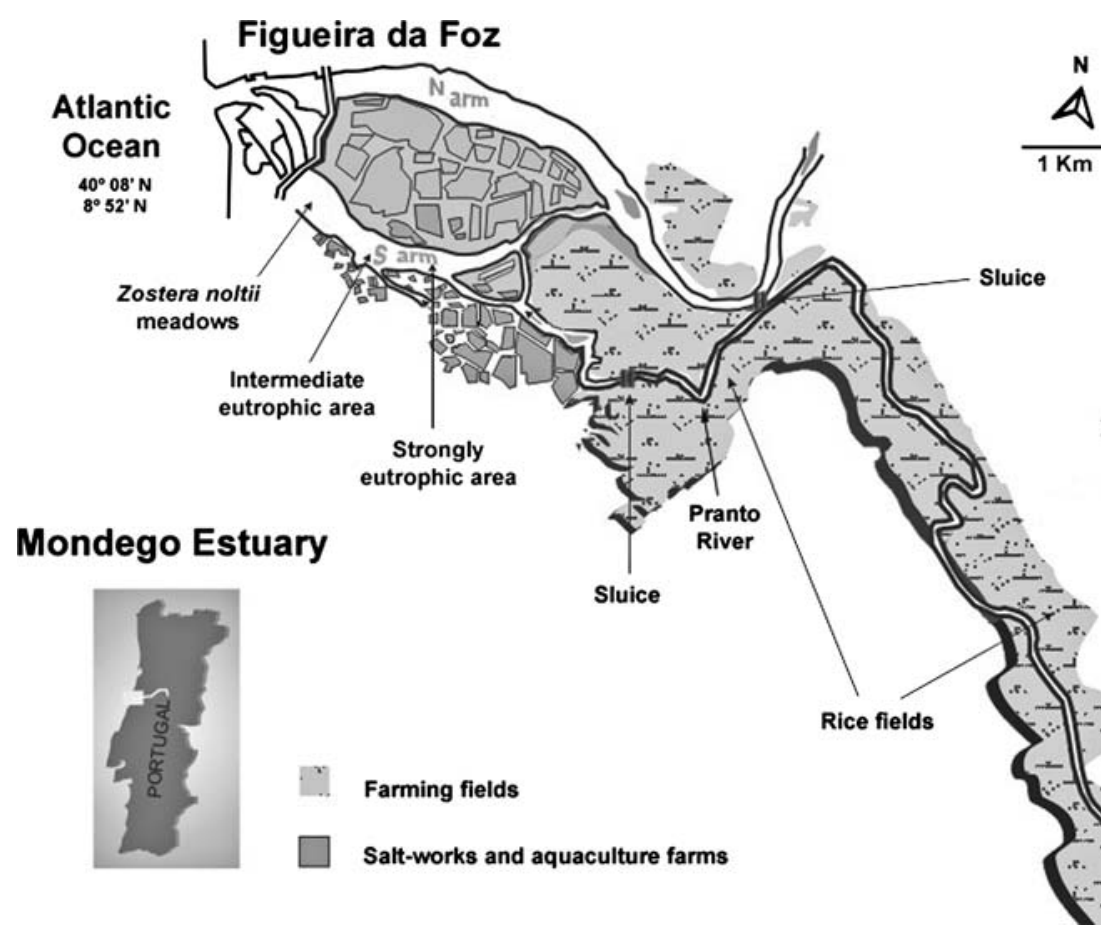

Figure 1. Mondego estuary: location of the sampling stations along a spatial gradient of eutrophication.

that salinity remains below the tolerance limit of macroalgae, coupled with a limitation of phosphorous induced by a heavy nitrogen discharge from the Pranto River (Martins et al., 2001).

Sampling was conducted in three areas in the southern arm of the Mondego estuary that represent different stages along a spatial gradient of eutrophication (Marques et al., 1997, Lillebø et al., 1999; Pardal et al., 2000, 2004; Cardoso et al., 2002; Dolbeth et al., 2003) (Fig. 1): (a) A non eutrophic area (Zostera noltii Hornem. beds), (b) an intermediate eutrophic area (Z. noltii absent, although residual roots can still be found in the sediment, and the occasional formation of abundant macroalgae mats) and (c) a strongly eutrophic area (macrophyte community totally absent for at least a decade and strong, regularly occurring blooms of Enteromorpha spp.).

\section{Methods}

Food webs of the ecosystem in the three areas were constructed using the 'Ecopath with Ecosim' software package, which assists the user in casting a balanced carbon budget for each trophic group. The core routine of Ecopath/Ecosim centres around the Ecopath program of Polovina (1984), which has been extended to apply to non-steady-state systems (Christensen \& Pauly, 2000). It no longer assumes a steady state but instead calculates parameters on the assumption of mass balance over an arbitrary period - usually one year. When applied, Ecopath derives model parameters on the basis of two master equations, one of which describes the production term and the other which ensures the balance of energy over each compartment. For further details of the Ecopath/Ecosim package see Christensen \& Pauly (2000) or visit $<$ http://www.ecopath.org/ $>$.

\section{Sampling program and laboratory treatment}

Chlorophyll a, detritus, macroalgae, macrophyte and macrofauna were sampled fortnightly (February 1993-January 1994), during low tide, at each of the three areas. All biological material was identified and separated into the lowest possible taxa (for more details concerning the technical procedures see Pardal et al., 2000, 2002). Between 
March 1996 and January 1997, monthly samples of epiphytes attached to Zostera noltii were separated from their substrate, dried and weighed. Zooplankton were collected monthly from subsurface waters at each sampling site from April 1995 to April 1996, using 200 and $335 \mu \mathrm{m}$ mesh nets (Azeiteiro, 1999). Data on fish were taken monthly from January 1991 to December 1992. The captured fish were identified and weighed (wet weight), and the dominant species in the stomach contents were analyzed (Jorge et al., 2002). Finally, wading birds were counted from January 1996 to January 1998 at fortnight-tide and monthly low-water to provide an accurate census across the three areas (Lopes et al., 2002). Seagulls were counted monthly, from November 1993 to July 1994.

\section{Compartments}

A different number of ecosystem compartments was identified in each system (Table 1): 43 in the Zostera meadows, 36 in the intermediate eutrophic area and 34 in the strongly eutrophic area.

\section{Biomass}

Chlorophyll a was estimated according to standard procedures (Strickland \& Parsons, 1968) and values were transformed into phytoplankton biomass using a conversion factor taken from Anderson \& Williams (1998) and assuming an average depth of $0,5 \mathrm{~m}$ over the sampling area. Epiphytes consisted only of the material attached to the aerial part of Zostera noltii. Plants and macrofauna were dried at $70{ }^{\circ} \mathrm{C}$ for $72 \mathrm{~h}$ and weighed. The ash free dry weight (AFDW) of biomass was assessed after combusting samples for $8 \mathrm{~h}$ at $450{ }^{\circ} \mathrm{C}$ (Pardal et al., 2000, 2002). The abundance of each zooplankton taxon was estimated by multiplying the observed number of that taxon by the average AFDW of an individual belonging to it. The weights of all taxa were summed to arrive at the annual average standing stock. Sixty-two species of fish were observed and were grouped according to their ecological and trophic characteristics. The biomass corresponding to each group was determined by multiplying its wet weight by a conversion factor taken from Jørgensen et al. (1991). The observed density of each bird species was multiplied by the average AFDW of an individual belonging to that taxon (as taken from the literature). Bacterial biomass was assigned to the detritus compartment, as recommended by Christensen \& Pauly (1992). Finally, the amount of organic matter in the sediment was assessed to be the weight lost after combustion of dry samples for $8 \mathrm{~h}$ at $450{ }^{\circ} \mathrm{C}$.

\section{Production, consumption and diet composition}

Production refers to the increase of tissue within a compartment over a given period. Whenever possible, Production/Biomass ratios $(\mathrm{P} / \mathrm{B})$, previously calculated for local populations (Allen, 1971), were used. When this was not feasible, values taken from the literature were utilized. Special care was exercised to identify values coming from similar Portuguese estuarine systems.

Consumption is the intake of food by a group over a given interval of time. It was entered into Ecopath as the ratio of consumption to biomass (Q/B). Q/B values for birds and fish were taken from the literature. For the other heterotrophic compartments, the production/biomass ratio was entered into the program to estimate indirectly the Q/B ratio (Hostens \& Hamerlynck, 1994).

In a trophic model, such as those constructed using the Ecopath, it is predation that links the different groups into a system. Consumption for one group becomes mortality for another, making information on predation paramount to understanding the dynamics of ecosystems. Unfortunately, quantitative information on diet composition is sparse. Diet information for almost all the compartments identified here had to be obtained from the literature (e.g. Hughes, 1969; Costa, 1982; Pihl, 1985; Zajac, 1986; Sprung, 1994; Ansell et al., 1999; Azeiteiro et al., 1999; Cunha et al., 2000; Pardal et al., 2000). Initially, all the prey items of each compartment of macrofauna and fishes were listed, along with their corresponding percentages of occurrence. Each observed dietary item was then assigned to an ecologically similar species or group of species as identified above. Finally, the percentage of occurrence in the diet was assumed to be proportional to the fraction that its biomass comprised the total biomass of the group. The diets of wading birds and gulls were obtained directly 
Table 1. System compartments along the three study areas

\begin{tabular}{|c|c|c|c|}
\hline Compartments & Zostera meadows & Intermediate eutrophic area & Strongly eutrophic area \\
\hline (1) Phytoplankton & $*$ & $*$ & $*$ \\
\hline (2) Enteromorpha spp (A) & $*$ & $*$ & $*$ \\
\hline (3) Ulva sp (A) & $*$ & $*$ & $*$ \\
\hline (4) Gracilaria sp (A) & $*$ & $*$ & $*$ \\
\hline (5) Fucus sp (A) & & $*$ & $*$ \\
\hline (6) Zostera noltii (M) & $*$ & & \\
\hline (7) Epiphytes & $*$ & & \\
\hline (8) Zooplankton & * & $*$ & $*$ \\
\hline (9) Hydrobia ulvae (G) & $*$ & $*$ & $*$ \\
\hline (10) Gibula umbilicalis $(\mathrm{G})$ & $*$ & & \\
\hline (11) Littorina $\operatorname{spp}(\mathrm{G})$ & $*$ & $*$ & \\
\hline (12) Melita palmata (Am) & $*$ & $*$ & $*$ \\
\hline (13) Ampithoe valida (Am) & * & $*$ & $*$ \\
\hline (14) Echinogammarus marinus (Am) & & & $*$ \\
\hline (15) Corophium multisetosum (Am) & & $*$ & \\
\hline (16) Scrobicularia plana (B) & $*$ & $*$ & $*$ \\
\hline (17) Cerastoderma edule (B) & $*$ & $*$ & $*$ \\
\hline (18) Modiolus barbatus (B) & $*$ & & \\
\hline (19) Cyathura carinata (I) & $*$ & $*$ & $*$ \\
\hline (20) Idotea chelipes (I) & $*$ & $*$ & $*$ \\
\hline (21) Sphaeroma hookeri (I) & $*$ & & \\
\hline (22) Carcinus maenas (D) & $*$ & $*$ & $*$ \\
\hline (23) Crangon crangon (D) & $*$ & $*$ & $*$ \\
\hline (24) Alkmaria romijni $(\mathrm{P})$ & $*$ & $*$ & $*$ \\
\hline (25) Capitella capitata $(\mathrm{P})$ & $*$ & $*$ & $*$ \\
\hline (26) Heteromastus filiformis $(\mathrm{P})$ & $*$ & $*$ & $*$ \\
\hline (27) Hediste diversicolor $(\mathrm{P})$ & $*$ & $*$ & $*$ \\
\hline (28) Diopatra neapolitana $(\mathrm{P})$ & * & & \\
\hline (29) Nephtys hombergii $(\mathrm{P})$ & $*$ & $*$ & \\
\hline (30) Lumbrineris impatiens $(\mathrm{P})$ & $*$ & & \\
\hline (31) Other macrofauna detritivores & $*$ & $*$ & $*$ \\
\hline (32) Other macrofauna predators & $*$ & $*$ & $*$ \\
\hline (33) Oligochaets & $*$ & $*$ & $*$ \\
\hline (34) Microalgae and detritus feeders (F) & $*$ & $*$ & $*$ \\
\hline (35) Zooplankton consumers (F) & $*$ & $*$ & $*$ \\
\hline (36) Endofauna consumers (F) & $*$ & $*$ & $*$ \\
\hline (37) Macrofauna predators (F) & $*$ & $*$ & $*$ \\
\hline (38) Trigla lucerna $(\mathrm{F})$ & $*$ & & \\
\hline (39) Pomatoschistus minutus (F) & $*$ & & \\
\hline (40) Larus ridibundus $(\mathrm{Gu})$ & $*$ & $*$ & $*$ \\
\hline (41) Larus fuscus $(\mathrm{Gu})$ & $*$ & $*$ & $*$ \\
\hline (42) Charadrius alexandrinus (W) & $*$ & $*$ & $*$ \\
\hline (43) Charadrius hiaticula (W) & $*$ & $*$ & $*$ \\
\hline (44) Pluvialis squatarola $(\mathrm{W})$ & $*$ & $*$ & $*$ \\
\hline (45) Calidris alpina (W) & $*$ & $*$ & $*$ \\
\hline (46) Detritus & $*$ & $*$ & $*$ \\
\hline
\end{tabular}

$\mathrm{A}=$ macroalgae, $\mathrm{M}=$ macrophyte, $\mathrm{G}=$ gastropoda, $\mathrm{Am}=$ amphipoda, $\mathrm{B}=$ bivalvia, $\mathrm{I}=$ isopoda, $\mathrm{D}=$ decapoda, $\mathrm{P}=$ polychaeta, $\mathrm{F}=$ fish, $\mathrm{Gu}=$ gull, $\mathrm{W}=$ wader. 
from an analysis of their droppings (Cabral et al., 1999; Moreira, 1995).

\section{Captures}

A complete network requires estimates of the rates of export from the system, including the harvests of economically important species. In the present work, the harvests of the bivalve Scrobicularia plana da Costa and the polychaete Hediste diversicolor (Müller) (the only two species of economic importance) were considered so small as to be negligible.

\section{System indices}

Estimates of consumption, production and respiration generated by Ecopath with Ecosim to calculate annual AFDW budgets for each heterotrophic compartment during one year were imported into the NETWRK 4.2a software (Ulanowicz, 1999). The structures of trophic levels and cycling for each network were analyzed, and the overall system properties were calculated using algorithms described by Ulanowicz (1986), Kay et al. (1989) and Monaco \& Ulanowicz (1997). Ulanowicz (1986) has characterized the developmental status of an ecosystem network in terms of a set of information-theoretic whole-system indices applied to the flow structure (see Table 2). Such global measurements include:

(1) The aforementioned total system throughput (TST), which is the sum of the magnitudes of all flows occurring in the system. Including consumptions, exports, respirations and flows into detritus. TST is a surrogate for the size of an ecosystem in the same sense that the extent of an economy may be reckoned in terms of the gross domestic product (Kay et al., 1989).

(2) The average mutual information (AMI), which represents the average amount of constraint exerted upon an arbitrary amount of mass as it flows from any one compartment to the next (Ulanowicz, 1997). It also measures the overall degree by which one compartment communicates unambiguously with any other (Rutledge et al., 1976.) Ulanowicz (1986) has suggested that both the number of trophic compartments and the extent of trophic specificity (the relative lack of trophic niche overlap) are embodied in the AMI of the flow connection between compartments. A network with high mutual information is a system with many nodes (compartments) of comparable size that are connected with each other (Baird et al., 1991). System development then becomes any increase in the AMI, which reflects increasing internal constraint within the ecosystem. Such constraints are thought to arise as autocatalytic feedback loops reinforce and increment their component pathways at the expense of other non-participating members.

(3) The ascendency $(A)$, which is the product of (1) by (2). The ascendency is the key index that characterizes the degree of system development and maturity. It incorporates both growth and development into the same index and, simultaneously, measures network's potential for competitive advantage over other network configurations (Ulanowicz, 1986).

(4) The development capacity $(C)$, which functions as a mathematical upper bound on the ascendency. Capacity is measured by the diversity of the flows (calculated using the Shannon-Wiener formula), as normalized by the total system throughput (Ulanowicz \& Norden, 1990). The capacity is so named, because it represents the scope of the system for further development.

Table 2. System indices algorithms. $\mathrm{T}_{p q}$, all possible transfers; $p$ and $q$, arbitrary system component or environment; $\mathrm{T}_{i j}$, trophic exchanges from taxon $i$ to taxon $j ;(n+1)$, import; $(n+2)$, export or dissipation. A dot as subscript indicates summation over that index

\begin{tabular}{ll}
\hline System indices & Algorithms \\
\hline $\begin{array}{l}\text { Total system } \\
\text { throughput, TST }\end{array}$ & TST $=\sum_{p, q} T_{p q}$ \\
$\begin{array}{l}\text { Average mutual } \\
\text { information, AMI }\end{array}$ & AMI $=\sum_{i, j} \frac{T_{i j}}{T . .} \log \left[\frac{\left.T_{i j} T_{. .}\right]}{\left.T_{i .} T_{j}\right]}\right.$ \\
Ascendency, $A$ & $A=\sum_{i} \sum_{j} T_{i j} \log \left[\frac{T_{i j} T_{. .}}{T_{i . j}}\right]$ \\
Development capacity, $C$ & $C=\sum_{i, j} T_{i j} \log \left[\frac{T_{i j}}{T_{. . .}}\right]$ \\
Overhead, $\Phi$ & $\Phi=-\sum_{i, j} T_{i j} \log \left(\frac{T_{i j}^{2}}{\sum_{k} T_{k j} \sum_{i} T_{i l}}\right)$ \\
Specific overhead, $\Phi / \mathrm{TST}$ & $\Phi / \mathrm{TST}=-\sum_{i, j=0}^{n+2} \frac{T_{i j}}{T . .} \log \left[\frac{T_{i j}^{2}}{T_{i . T_{j}}}\right]$ \\
\hline
\end{tabular}


(5) The system overhead (Ø), which is the (nonnegative) amount by which the capacity, $C$, exceeds the ascendency, $A$. (Baird et al., 1991). The overhead is generated by structural ambiguities deriving from multiplicities in the system inputs, exports, dissipations and internal exchanges (functional redundancy). It quantifies the system's residual "freedom" and represents its potential for recovery or innovative restructuring.

(6) The specific overhead of the system $(\varnothing / T S T)$, which is the total flexibility of the system calculated on a per- unit- flow basis. It consists mostly of pathway redundancy, but in open systems it is also augmented by multiplicities in the external inputs and outputs.

\section{Results}

Table 3 summarizes the ecological statistic and indices for the three estuarine networks. The sum of consumptions, exports, respiration, production and flow to detritus was always higher in the Zostera meadows, followed by the strongly eutrophic area and, finally, by the intermediate eutrophic area. The annual rate of net primary production presented a similar behaviour, clearly related with the primary producers' dynamic in each of the studied areas.

Computed values for the total system throughput, development capacity, average mutual information and ascendency (Table 4) were all clearly higher in the non-eutrophic area, and were followed by those for the strongly eutrophic system. The rankings in specific overhead (Table 4) mirrored those in the redundancy (which comprises the largest component of $\varnothing /$ TST), with the highest values being calculated for the intermediate eutrophic area.

The energy flow networks pertaining to the non-eutrophic and the strongly eutrophic areas were aggregated into their canonical trophic forms (Fig. 2), otherwise known as the 'Lindeman spine'. Regarding the trophic analysis, the Zostera meadows presented one more trophic level than those counted in the strongly eutrophic chain, however this area exhibited lower transfer efficiency at the first trophic level (14.8\%).

Concerning the magnitude of recycling activity, the overall percentage of cycled matter, as indicated by the Finn cycling index, increased along with the degree of eutrophication (Table 4). The total number of cycles (Table 4) was the highest in the Zostera meadows (74517), followed by the intermediate eutrophic area (15009) and the fewest were counted in the strongly eutrophic area (9164). With regards to the major routes of recycling identified as a result of this study (Fig. 3), it becomes evident that material was flowing over a more complicated web of cycles in the Zostera community. It is also evident that the keys species, implicated in the cycle process, changed from one community to the other.

After all, comparing the behaviour of the ascendency with other ecological indicators (Table 5), showed that the heterogeneity (as computed using the Shanon-Wiener index) and the

Table 3. Summary of ecological statistic/ indices for the three estuarine networks

\begin{tabular}{|c|c|c|c|}
\hline Statistic/indices & Zostera meadows & Intermediate eutrophic area & Strongly eutrophic area \\
\hline Sum of consumption (g AFDW $\mathrm{m}^{-2} \mathrm{y}^{-1}$ ) & 700.67 & 297.25 & 525.72 \\
\hline Sum of exports (g AFDW m ${ }^{-2} \mathrm{y}^{-1}$ ) & 1707.51 & 34.01 & 169.61 \\
\hline Sum of respiration (g AFDW m ${ }^{-2} y^{-1}$ ) & 2322.55 & 297.32 & 612.67 \\
\hline Flow to detritus (g AFDW $\mathrm{m}^{-2} \mathrm{y}^{-1}$ ) & 2092.06 & 195.09 & 522.40 \\
\hline Sum to production (g AFDW m ${ }^{-2} \mathrm{y}^{-1}$ ) & 2151 & 223 & 494 \\
\hline Net primary production (g AFDW $\mathrm{m}^{-2} \mathrm{y}^{-1}$ ) & 2014.83 & 165.58 & 391.065 \\
\hline Total primary production/total respiration & 0.868 & 0.557 & 0.638 \\
\hline Total biomass/Total system throughput & 0.045 & 0.061 & 0.076 \\
\hline Total biomass (no detritus) (g AFDW m ${ }^{-2}$ ) & 304.18 & 49.91 & 139.24 \\
\hline Omnivory index & 0.105 & 0.110 & 0.202 \\
\hline
\end{tabular}


Table 4. Network analysis ecosystem indices for the three areas

\begin{tabular}{lccc}
\hline Information indices & Zostera meadows & Intermediate eutrophic area & Strongly eutrophic area \\
\hline Total System Throughput (g AFDW m-2 y-1) & 10852 & 1154.8 & 2612.5 \\
Development Capacity (g AFDW m-2 y-1; bits) & 39126 & 5695.2 & 10831 \\
Ascendency (\%) & 42.3 & 30.4 & 36.7 \\
Overhead on imports (\%) & 12.3 & 8.2 & 6.2 \\
Overhead on exports (\%) & 1.3 & 1.5 & 2.5 \\
Dissipative overhead (\%) & 17.7 & 22.1 & 19.9 \\
Redundancy (\%) & 26.4 & 37.8 & 34.6 \\
Average Mutual Information (bits) & 1.525 & 1.498 & 1.522 \\
Specific Overhead & 2.080 & 3.432 & 2.623 \\
Connectance indices & & & 2.11 \\
Overall connectance & 1.672 & 2.431 & 0.1946 \\
Finn cycling index & $5.75 \mathrm{E}-02$ & 0.2045 & 9164 \\
Total number of cycles & 74517 & 15009 & \\
\hline
\end{tabular}
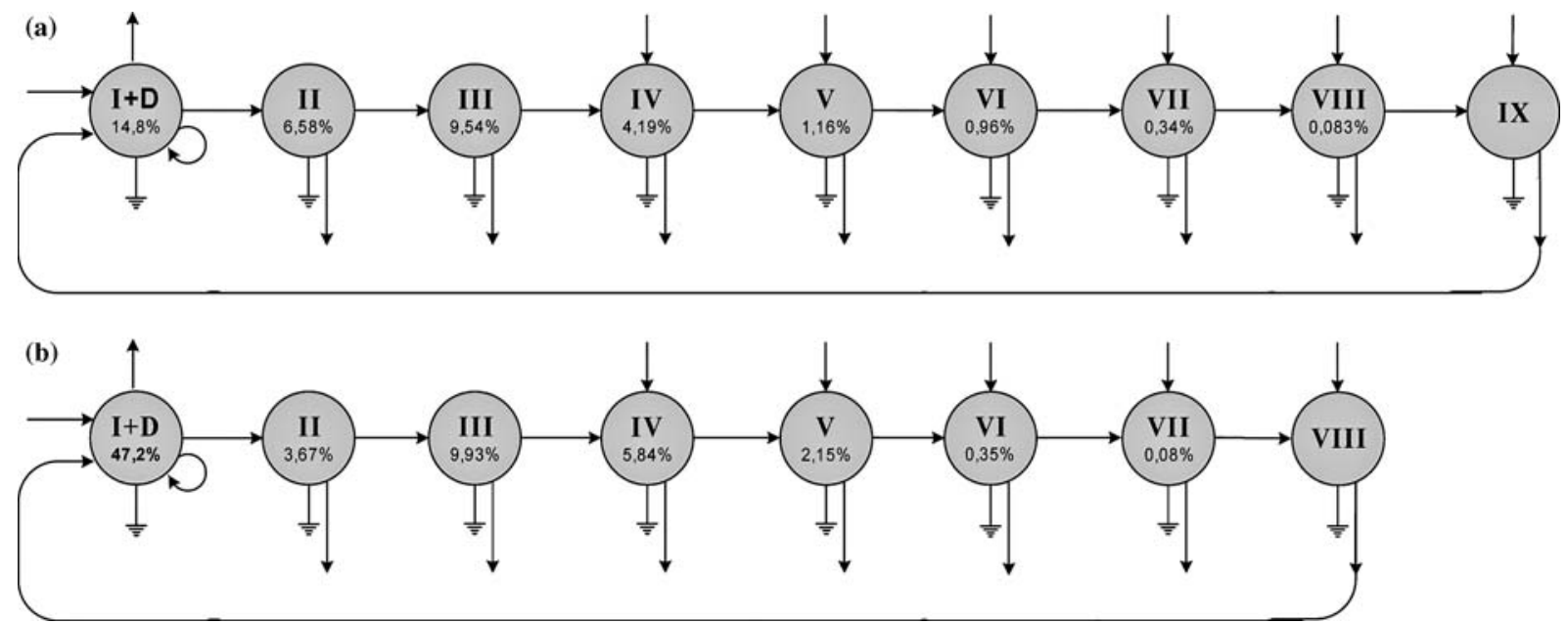

Figure 2. Qualitative representation of linear food chains: (a) Zostera noltii meadows and (b) strongly eutrophic area. Flows out of compartment boxes represent exports, flows arriving to compartment boxes represent exogenous system inputs and flows out of the bottom represent respiration. Level I + D corresponds to the association of autotrophs (level 1) and Detritus (non-living compartment). The heterotrophic compartments are divided in levels II-IX (in a) or levels II-VIII (in b), according to their diets.

specific exergy (a thermodynamic measure indicating the amount of work the system can perform on a per- unit- mass basis), both increased with greater eutrophication. On the other hand, species richness, ascendency and total exergy declined with the degree of eutrophication.

\section{Discussion}

A long-term study in the Mondego estuary has indicated that years of low precipitation have been associated with reductions in turnover rates and with increases in water column stability, salinity and light penetration (Martins et al., 2001). These changes in habitat conditions favoured the initiation of macroalgal blooms, which then served to depress the previously dominant macrophyte communities (Marques et al., 1997; Martins et al., 2001; Cardoso et al., 2002; Dolbeth et al., 2003). In the intermediate and strongly eutrophic areas, primary production is largely the result of such macroalgal blooms (Marques et al., 1997). As a consequence, production in these two systems 


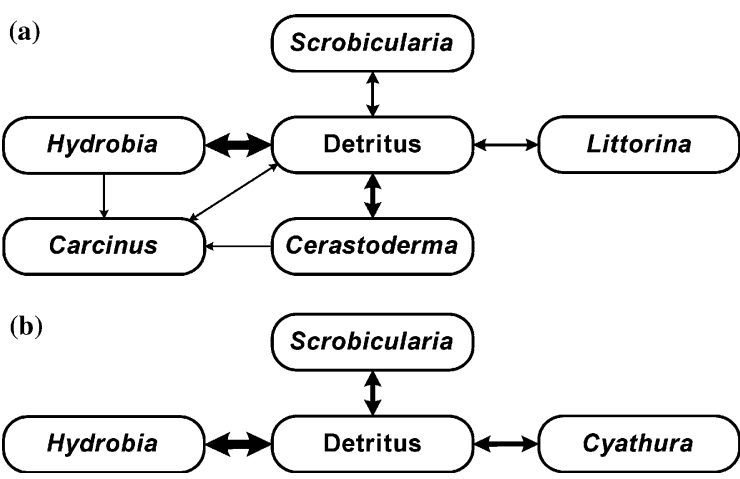

Figure 3. Cycling diagrams: (a) Diagram of those compartments involved in $91 \%$ of the cycled flow $\left(\mathrm{g}_{\text {AFDW m}} \mathrm{y}^{-1}\right.$ ) in Zostera noltii meadows, (b) The compartments involved in $92 \%$ of the cycled flow ( $\mathrm{g}$ AFDW m $\mathrm{m}^{-2} \mathrm{y}^{-1}$ ) in the strongly eutrophic ecosystem.

appears as a strong pulse during the course of the blooms, but remains at very low levels for the rest of the year (Dolbeth et al., 2003). The short duration of the abundant primary production in these areas averages over the year to a significantly lower annual rate of net primary production. Odum (1969) had suggested that less-impacted systems (e.g. Zostera beds) should exhibit higher rates of net system production - a fact that is consistent with the results of the current study.

When the whole-system properties of the three areas were compared, an interesting pattern emerged. The measures associated with the intermediate eutrophic area did not fall between those calculated at the ends of the gradient. Rather, the intermediate eutrophic system exhibited the lowest values for ascendency, AMI, TST and development capacity and the highest values for redundancy, $\varnothing /$ TST and FCI (Table 4). That is, by all indications it seemed to be the most disturbed of the three systems. Because ascendency is scaled by the flows of material in a system, it is likely to be dominated in the Zostera meadows and the strongly eutrophic site by the primary producers seagrasses and macroalgal mats, respectively. At the intermediate site there is little macroalgal material and no seagrasses, resulting in a lower value for ascendency. A second, and not mutually exclusive, explanation is that the non-disturbed and most disturbed sites host relatively stable communities - one dominated by seagrasses and fine sediments, and the other by macroalgal mats and coarser material. When the seagrasses are lost, however, there is a coarsening of the sediments, which makes it very difficult for seagrasses to re-invade. The reason for the depressed values found in the intermediate eutrophic area, therefore, appears to lie in its unstable nature (Marques et al., 2003).

The canonical form reveals how the ecosystem is functioning in terms of its embedded, distinct trophic levels. The Zostera beds (Fig. 2a) are seen to have an additional trophic level beyond those visible in the strongly eutrophic chain, implying that this community possesses a more developed web with additional top consumers. The unimpacted community, however, presented a lower transfer efficiency at the first trophic level, probably because the macrophyte production usually cannot be consumed directly, but needs first to be decomposed (Lillebø et al., 1999). The intermediate eutrophic area was the most effective one in transferring material $(8.9 \%)$ at the second trophic level.

Although the Finn cycling index, increased along with the degree of eutrophication, the structure of cycling changed dramatically between the unimpacted and the eutrophic systems. The total number of cycles decreased along the gradient, due to the tendency for a larger number of cycles to be found among systems possessing more

Table 5. Ecological indicators along the eutrophication gradient

\begin{tabular}{|c|c|c|c|c|}
\hline \multicolumn{2}{|c|}{ Ecological indicators } & \multirow{2}{*}{$\begin{array}{l}\text { Zostera meadows } \\
1.80\end{array}$} & \multirow{2}{*}{$\begin{array}{l}\text { Intermediate eutrophic area } \\
1.51\end{array}$} & \multirow{2}{*}{$\begin{array}{l}\text { Strongly eutrophic area } \\
1.21\end{array}$} \\
\hline Biodiversity & Species diversity & & & \\
\hline & Heterogeneity & 0.99 & 1.46 & 1.52 \\
\hline \multicolumn{2}{|c|}{ Specific Exergy } & 85.70 & 150.29 & 165.42 \\
\hline \multicolumn{2}{|l|}{ Exergy } & 25364 & 4789 & 8547 \\
\hline \multicolumn{2}{|l|}{ Ascendency } & 42.3 & 30.4 & 36.7 \\
\hline
\end{tabular}


compartments at higher trophic levels. Looking at the major routes of recycling, it becomes evident that material was flowing over a more complicated web of cycles in the Zostera community. Odum (1969) has suggested that mature ecosystems recycle a greater percentage of their constituent material and energy than do pioneer or disturbed communities. Hence, according to Odum, the progressive increase in the FCI would suggest a maturation of the ecosystem. It has been observed, however, that disturbed systems also often exhibit greater degrees of recycling. The speculation is that such increase in cycling in disturbed systems is the homeostatic response that maintains in circulation resources which before the perturbation had been stored as biomass in the higher organisms (Ulanowicz, 1984; Ulanowicz \& Wulff, 1991). This latter scenario seems consistent with the present results.

In the light of these results, the network definition of eutrophication (Ulanowicz, 1986) does not appear to accord with the gradient in eutrophication in the Mondego estuarine ecosystem. Rather, it would seem more accurate to describe the effects of eutrophication process in this ecosystem in terms of a disturbance to system ascendency caused by an intermittent supply of excess nutrients that, when coupled with a combination of physical factors (e.g. salinity, precipitation, etc), causes both a decrease in system activity and a drop in the mutual information of the flow structure. Even though a significant rise in the total system throughput does occur during the period of the algal bloom and does at that time give rise to a strong increase of the system ascendency, the longer-term, annual picture suggests instead that the non-bloom components of the intermediate and strongly eutrophic communities were unable to accommodate the pulse in production. The overall result was a decrease in the annual value of the system TST and, as a consequence, of the annual ascendency as well.

Comparing the behaviour of the ascendency with the more traditional ecological indicators revealed that the heterogeneity and the specific exergy both increased monotonically with greater eutrophication (Marques et al., 1997). Species richness, ascendency and total exergy; however, declined, as expected, with the degree of eutrophication. These results argue in favour of using a pluralistic approach to evaluating the effects of adding nutrients to ecosystems.

Despite the considerable time and labour required for data acquisition and network analysis, the insights provided by holistic measures, such as the ones discussed above, demonstrate their utility as useful tools in ecosystem analysis and environmental quality assessment.

\section{Acknowledgements}

The present study was carried out in the scope of the research project DYNAMOD (POCTI/ M6S137431/2001) and supported by FCT (Portuguese National Board of Scientific Research) through a grant $\mathrm{SFRH} / \mathrm{BD} / 820 / 2000$, and by the IMAR-Institute of Marine research /FLAD Grants program. The second author received support through a grant from the National Science Foundation's Biocomplexity Program (Contract No. DEB-9981328).

\section{References}

Allen, P. M., 1971. Relation between production and biomass. Journal of Fisheries Research Board of Canada 28: 1573-1581.

Almunia, J., G. Basterretxea, J. Aristegui \& R. E. Ulanowicz, 1999. Benthic-pelagic switching in a coastal subtropical lagoon. Estuarine, Coastal and Shelf Science 49: 363-384.

Anderson, T. R., P. J. le \& B. Williams, 1998. Modelling the seasonal cycle of dissolved organic carbon at station E1 in the English Channel. Estuarine, Coastal and Shelf Science 46: 93-109.

Ansell, A. D., C. A. Comely \& L. Robb, 1999. Distribution, movements and diets of macrocrustaceans on a Scottish sandy beach with particular reference to predation on juvenile fishes. Marine Ecology Progress Series 176: 115-130.

Azeiteiro, U. M., J. C. Marques \& P. Ré, 1999. Zooplankton annual cycle in the Mondego river estuary (Portugal). Arquivos do Museu Bocage III: 239-264.

Baird, D. \& R. E. Ulanowicz, 1989. The seasonal dynamics of the Chesapeak Bay ecosystem. Ecological Monographs 59: 329-364.

Baird, D., J. M. MacGlade \& R. E. Ulanowicz, 1991. The comparative ecology of six marine ecosystems. Philosophical Transactions of the Royal Society of London 333: 15-29.

Baird, D. \& J. J. Heymans, 1996. Assessment of ecosystem changes in response to freshwater inflow of the Kromme River Estuary, St Francis Bay, South Africa: a network analysis approach. Water SA 22: 307-318. 
Cabral, J. A., M. A. Pardal, R. J. Lopes, T. Múrias \& J. C. Marques, 1999. The impact of macroalgal blooms on the use of the intertidal area and feeding behaviour of waders (Charadrii) in the Mondego estuary (West Portugal). Acta Oecologica 20(4): 417-428.

Cardoso, P. G., A. I. Lillebø, M. A. Pardal, S. Ferreira \& J. C. Marques, 2002. The effect of different primary producers on Hydrobia ulvae population dynamics. A case study in a temperate intertidal estuary. Journal of Experimental Marine Biology and Ecology 277(2): 173-195.

Christensen V. \& D. Pauly, 1992. A guide to the Ecopath II program (version 2.1). ICLARM Software. pp. 6-72.

Christensen V., C. J. Walters \& D. Pauly, 2000. Ecopath with Ecosim: a User's Guide, October 2000 Edition. Fisheries Centre, University of British Columbia, Vancouver Canada and ICLARM Penang, Malaysia 130 pp.

Cloern, J. E., 2001. Our evolving conceptual model of the coastal eutrophication problem. Marine Ecology and Progress Series 210: 223-253.

Constanza, R., 1992. Toward an operational definition of ecosystem health. In Constanza, R. B. G. Norton, \& B. D. Haskell (eds.) Ecosystem health: new goals for environmental management. Island Press, Washington D.C: 269 pp.

Costa M.J., 1982. Contribution à l'étude de l'écologie des poissons de l'estuaire du Tage (Portugal). Thèse P. Grade docteur ès-sciences. Université Paris VII, $256 \mathrm{pp}$.

Cunha, M. R., M. H. Moreira \& J. C. Sorbe, 2000. The amphipod Corophium multisetosum (Corophiidae) in Ria de Aveiro (NW Portugal).II.Abundance, biomass and production. Marine Biology 137: 651-660.

Diaz, R. J. \& R. Rosenberg, 1995. Marine benthic hypoxia: a review of its ecological effects and the behavioural responses of benthic macrofauna. Oceanography and Marine Biology:anAnnual Review 33: 245-303.

Dolbeth M., M. A. Pardal, A. I. Lillebø, U. Azeiteiro \& J. C. Marques, 2003. Short- and long- term effects of eutrophication on the secondary production of an intertidal macrobenthic community. Marine Biology 143: 1229-1238.

Flindt, M. R., L. Kamp-Nielsen, J. C. Marques, M. A. Pardal, M. Bocci, G. Bendoricchio, S. N. Nielsen \& S. E. Jørgensen, 1997. Description and comparation of the three shallow estuaries: Mondego river (Portugal), Roskield Fjord (Denmark) and the lagoon of Venice (Italy). Ecological Modelling 102: 17-31.

Halfon, E., N. Schito \& R. E. Ulanowicz, 1996. Energy flow through the Lake Ontario food web: conceptual model and attempt at mass balance. Ecological Modelling 86: 1-36.

Heymans, J. J. \& D. Baird, 1995. Energy flow in the Kromme estuarine ecosystem, St. Francis Bay, South Africa. Estuarine, Coastal and Shelf Science 41: 39-59.

Heymans, J. J. \& D. Baird, 2000. A carbon flow model and network analysis of the northern Benguela upwelling system, Namibia. Ecological Modelling 126: 9-32.

Hostens, K. \& O. Hamerlynck, 1994. The mobile epifauna of the soft bottoms in the subtidal Oosterscheld Estuary: structure, function and impact of the storm-surge barrier. Hydrobiologia 282/283: 479-496.

Hughes, R. N., 1969. A study of feeding in Scrobicularia plana. Journal of the Marine Biological Association of the United Kingdom 49: 805-23.
Kay, J. J., L. A. Graham \& R. E. Ulanowicz, 1989. A detailed guide to network analysis. In Wulff, F. J. G. Field, \& K. H. Mann (eds.) Network Analysis in Marine Ecosystems: Methods and Applications. Springer- Verlag, Heidelberg: $15-61$.

Jorge, I., C. C. Monteiro \& G. Lasserre, 2002. Fish community of Mondego estuary: space-temporal organisation. In Pardal, M. A. J. C. Marques, \& M. A. Graça (eds.) Aquatic Ecology of the Mondego River Basin. 2 Global Importance of Local Experience, Imprensa da Universidade de Coimbra: 199- 219.

Jørgensen, S. E., 1997. Integration of Ecosystem Theories: A Pattern ( 2 nd ed.). Kluwer Academic Publishers, The Netherlands $388 \mathrm{pp}$.

Jørgensen, S. E., S. N. Nielsen \& L. A. Jørgensen, 1991. Handbook of Ecological Parameters and Ecotoxicology. Elsevier Science Publishers, Amsterdam, The Netherlands $1263 \mathrm{pp}$.

Lillebø, A. I., M. A. Pardal \& J. C. Marques, 1999. Population structure, dynamics and production of Hydrobia ulvae (Pennant) (Mollusca: Prosobranchia) along an eutrophication gradient in the Mondego estuary (Portugal). Acta Oecologica 20(4): 289-304.

Lopes, R. J, J. A. Cabral, C. Pacheco, T. Múrias \& J. C. Marques, 2002. Status and habitat use of waders in the Mondego estuary. In Pardal., M. A. J. C. Marques, \& M. A. Graça (eds.) Aquatic Ecology of the Mondego River Basin. 2 Global Importance of Local Experience, Imprensa da Universidade de Coimbra: 219-230.

Marques, J. C., M. A. Pardal, S. N. Nielsen \& S. E. Jørgensen, 1997. Analysis of the properties of exergy and biodiversity along an estuarine gradient of eutrophication. Ecological Modelling 102: 155-167.

Marques, J. C., S. N. Nielsen, M. A. Pardal \& S. E. Jørgensen, 2003. Impact of eutrophication and river management within a framework of ecosystem theories. Ecological Modelling 166(1-2): 147-168.

Martins, I. I., M. A. Pardal, A. I. Lillebø, M. R. Flindt \& J. C. Marques, 2001. Hydrodynamics as a major factor controlling the occurrence of green macroalgal blooms in a Eutrophic estuary. A case study on the influence of precipitation and river management. Estuarine, Coastal and Shelf Science 52: $165-177$.

Monaco, M. E. \& R. E. Ulanowicz, 1997. Comparative ecosystem trophic structure of three U.S.mid-Atlantic estuaries. Marine Ecology Progress Series 161: 239-254.

Moreira F. M., 1995. A utilização das zonas entre-marés do estuário do Tejo por aves aquáticas e suas implicações para os fluxos de energia na teia trófica estuarina. PhD Thesis, University of Lisbon.

Norkko, A. \& E. Bonsdorff, 1996. Rapid zoobenthic community responses to accumulations of drifting algae. Marine Ecology Progress Series 131: 143-157.

Pardal, M. A., J. C. Marques, I. Metelo, A. I. Lillebø \& M. R. Flindt, 2000. Impact of eutrophication on the life cycle, population dynamics and production of Ampithoe valida (Amphipoda) along an estuarine spatial gradient (Mondego estuary, Portugal). Marine Ecology Progress Series 196: 207-219. 
Pardal, M. A., Marques, J. C. Graça, M. A. (eds.) 2002. Aquatic Ecology of the Mondego River Basin. Global Importance of Local Experience, Imprensa da Universidade de Coimbra 576 pp.

Pardal, M. A., P. G. Cardoso, J. P. Sousa, J. C. Marques \& D. Raffaelli, 2004. Assessing environmental quality: a novel approach. Marine Ecology Progress Series 267: 1-8.

Patten B. C., B. D. Fath, J. S. Choi, S. Bastianoni, S. R. Borret, S. Brandt-Williams, M. Debeljak, J. Fonseca, W. E. Grant, D. Karnawati, J. C. Marques, A. Mosere, F. Müller, C. Pahl-Wostl, R. Seppelt, W. H. Steinborn \& Yu. M. Svirezhev, 2002 a. Complex Adaptive Hierarchical Systems chapter 3. In Costanza, B. \& S. E. Jorgensen (eds.), Understanding and Solving Environmental Problems in the 21st Century, Elsevier: 41-94.

Patten, B. C., B. D. Fath, J. S. Choi, S. Bastianoni, S. R. Borret, S. Brandt-Williams, M. Debeljak, J. Fonseca, W. E. Grant, D. Karnawati, J. C. Marques, A. Mosere, F. Müller, C. Pahl-Wostl, R. Seppelt, W. H. Steinborn \& Yu. M. Svirezhev, 2002 b. Complex Adaptive Hierarchical Systems chapter 4. In Costanza, B. \& S. E. Jorgensen (eds), Understanding and Solving Environmental Problems in the 21st Century, Elsevier: 95-99.

Pihl, L., 1985. Food selection and consumption of mobile epibenthic fauna in shallow marine areas. Marine Ecology Progress Series 22: 169-179.

Polovina, J. J., 1984. Model of a coral reef ecosystem I. The ECOPATH model and its application to French Frigate Shoals. Coral Reefs 3: 1-11.

Raffaelli, D., J. A. Raven \& L. J. Poole, 1998. Ecological impact of green macroalgal blooms. Oceanography and Marine Biology: an Annual Review 36: 97-125.

Ray, S., R. E. Ulanowicz, N. C. Majee \& A. B. Roy, 2000. Network analysis of a benthic food web model of a partly reclaimed island in the sundarban mangrove ecosystem, India. Journal of Biological Systems 8(3): 263-278.

Rutledge, R. W., B. L. Basorre \& R. J. Mulholland, 1976. Ecological stability: an information theory viewpoint. Journal of Theoretical Biology 57: 355-371.

Sprung, M., 1994. Macrobenthic secondary production in the intertidal zone of the Ria Formosa- a lagoon in southern Portugal. Estuarine, Coastal and Shelf Science 38: 539-558.
Strickland, J. D. \& T. R. Parsons, 1968. A practical hand-book of seawater analysis. Bulletin of Fisheries Research Board of Canada 167: 1-311.

Ulanowicz, R. E., 1980. An hypothesis on the development of natural communities. Journal of Theoretical Biology 85: 223-245.

Ulanowicz, R. E., 1984. Community measures of marine food networks and their possible applications. In Fasham, M. J. R. (ed.) Flows of Energy and Materials in Marine Ecosystems. Plenum, London: pp. 23-47.

Ulanowicz, R. E., 1986. A phenomenological perspective of ecological development. In Poston, T. M. \& R. Purdy (eds.) Aquatic Toxicology and Environmental Fate. Vol. 9, ASTM STP 921. American Society for Testing and Materials, Philadelphia, USA: 73-81.

Ulanowicz, R. E. \& F. Wulff, 1991. Comparing ecosystems structures: the Chesapeake Bay and the Baltic Sea. In Cole, J., G. Lovett \& S. Findlay (eds.), Comparative Analyses of Ecosystems: Patterns, Mechanisms and Theories. Springer Verlag: 140-166.

Ulanowicz, R. E., 1997. Ecology, the Ascendent Perspective. Columbia University Press, New York 201 pp.

Ulanowicz, R. E., 1999. NETWRK 4.2a: A package of computer algorithms to analyse ecological flow networks. Solomons, MD, US

Ulanowicz, R. E. \& J. S. Norden, 1990. Symmetrical overhead in flow and networks. International Journal of Systems Science 21(2): 429-437.

Weaver, M. J., J. J. Magnuson \& M. K. Clayton, 1997. Distribution of littoral fishes in structurally complex macrophytes. Canadian Journal of Fisheries and Aquatic Sciences 54: 2277-2289.

Wolff, M., H. J. Hartmann \& V. Koch, 1996. A pilot trophic model for Golfo Dulce, a fjord-like tropical embayment, Costa Rica. Revista de Biologia Tropical 44(3): 215-231.

Zajac, R. M., 1986. The effects of intra-specific density and food supply on growth and reproduction in an infaunal polychaete, Polydora ligni Webster. Journal of Marine Research 44: 339-359.

Zorach, A. C. \& R. E. Ulanowicz, 2003. Quantifying the complexity of flow networks: How many roles are there? Complexity 8(3): 68-76. 